日本における Neuraxial anesthesia と合併症 : その予防と対策

硬膜外麻酔の合併症症例

佐倉伸一*1 原かおる*2

[要旨] 硬膜外麻酔はその有用性から長い間標準的な区域麻酔として周術期に使用されてきた.し かし, 硬膜外麻酔には常に合併症のリスクもある. 合併症の多くは, 悪心・嘔吐, 低血圧, 尿閉な ど比較的軽度で投与している薬剤の減量や中止で対処可能なものであるが, 硬膜外血腫, 硬膜外膿 瘍など, まれではあっても重篤な合併症も起こりうる. 本稿では, 自施設で発生したものや, 日本 で発生し誌上や学会で報告された硬膜外麻酔・ブロックの合併症症例を紹介した. さまざまな合併 症が起こりうるので, 早期発見・対処するために教育と周術期管理体制の充実が重要である.

キーワード : 硬膜外麻酔, 合併症, 硬膜外血腫, 硬膜外膿瘍

\section{はじめに}

硬膜外麻酔は疼痛緩和に有効であるだけでなく， 周術期には全身麻酔と比較して術後の呼吸・循環器 合併症の発生率や死亡率を低下させる可能性がある ことから，長い間標準的な区域麻酔として使用され てきた。しかし, 硬膜外麻酔・ブロックには合併症 が発生するリスクもある。合併症の多くは，悪心・ 嘔吐，低血圧，尿閉など比較的軽度で投与している 薬剤の減量や中止で対処可能なものであるが，中に は患者の満足度を低下させるだけでなく, 対処に苦 慮するものもある。まれではあっても硬膜外血腫の ような重篤な合併症もある。本稿では, 硬膜外麻酔・ ブロックの合併症症例について自施設で発生したも の，日本で発生し誌上や学会で発表されてきたもの を中心に紹介する。

\section{I＼cjkstart硬膜外麻酔による合併症の発生頻度}

リスク・ベネフィットの観点から硬膜外麻酔を行 うかどうか判断するために合併症の発生頻度を知る ことは有用だが，正確に調べることは難しい，世界 的にも closed claims studyのようなものはあるが, 重篤でも訴訟に至らない症例の数を把握したり，症 状が軽症のものを拾い上げる調査を大規模に行うこ とは困難である。しかし，硬膜外血腫や膿瘍などの 重大な合併症について発生頻度を調べる研究は行わ れてきた。その一つに，スイスの単一施設で 2003 年から 2012 年の 10 年間に行われた胸部硬膜外鎮痛 7,273 例について後ろ向き調査で合併症の発生頻度 を調べたものがある ${ }^{11}$ 。重大な合併症のうち硬膜外 膿瘍，永久的神経損傷，心停止は各 1 例ずつであっ た。ほかにはカテーテルの断裂による体内遺残が 4 例，一時的な神経障害が 20 例あった。しかし，手 技を行ったが硬膜外鎮痛が不成功だった症例が含ま

${ }^{* 1}$ 島根大学医学部附属病院手術部

$* 2$ 松江生協病院麻酔科
著者連絡先 原かおる

干 690-8522 島根県松江市西津田 8-8-8 松江生協病院麻酔科 


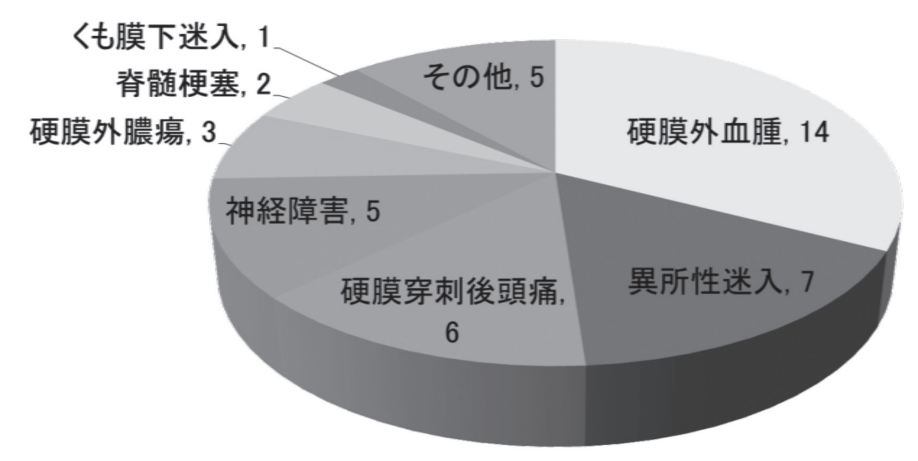

図1 全国学会症例報告件数

〔日本臨床麻酔学会 (2012 2018), 日本区域麻酔学会 (2015 〜2019)より了

れていないことなどから合併症のある症例が見落と されている可能性がある.

日本での大規模研究は見当たらなかったので, 2012 年から 2018年までの日本臨床麻酔学会と 2015 年から 2019 年までの日本区域麻酔学会の抄録を調 べ，硬膜外麻酔による合併症の症例報告件数をグラ フで示した(図1)。学会の症例報告は報告に值する ような目新しい点, 何か注意喚起を行いたい場合に 行われるため, 発生頻度を反映したものとは言えな いが, 硬膜外血腫の報告が 14 件と最も多く, 発生 を予防するために検査や併用薬の確認などいろいろ な対策がなされているにもかかわらず，近年も発生 しており，かつ注目度も高い合併症であることがう かがえる。

次に各合併症別に紹介する.

\section{II 各合併症の症例}

\section{1. 硬膜外血腫}

硬膜外血腫は，早い時期からさまざまな報告があ る最も有名な合併症の一つである.

海外では，1970年に抗血栓療法と硬膜外麻酔の 組み合わせで発生した最初の症例報告が ${ }^{2)}$ ，また， 1995年には肝硬変患者に行った硬膜外麻酔後の血 腫の最初の症例報告が国内から発表されている ${ }^{3)}$. その後も硬膜外血腫については対象患者による発生
頻度の違いなど数多くの研究報告がされている ${ }^{4)}$.

国内で誌上報告された脊椎の変形やもともとあっ た春椎疾患が硬膜外血腫の原因となったと考えられ た症例報告を 2 つ紹介する。

最初の症例は76歳の男性で, 胃癌に対する幽門 側胃切除術と頸髄症に対する第 3 第 6 頸椎の拡大 術の手術歴があった ${ }^{5)}$. 残胃癌に対し, 残胃全摘と 脾膵尾部合併切除が予定された。術前の血液凝固系 検査はすべて正常範囲内であった。硬膜外麻酔併用 全身麻酔を予定し，第 $9 / 10$ 胸椎間から硬膜外腔穿 刺を行い，カテーテルを $6 \mathrm{~cm}$ 挿入した。術中は 0.5 \%メピバカイン, 術後はフェンタニル, ドロペリド ール混合の $0.14 \%$ ロピバカインを $4 \mathrm{~mL} / \mathrm{h}$ で投与し た。術後疼痛コントロールは良好であった。術後 1 日目の朝, 両下肢麻痺の自覚があるも術中体位によ るものと判断されていた。同日 15 時，麻酔科医が 硬膜外持続注入を中止し，その後足趾の運動は改善 した。術後 2 日目, 硬膜外カテーテルは抜去された。 この時血液凝固能は正常であった。下肢の運動麻痺 が持続していたため MRI検査を行った結果，硬膜 外血腫を示唆する所見があった。胸腰椎の高度な脊 柱管狭窄症があることもわかった。血腫自体は少量 でも狭窄症が影響して麻痺が生じていた可能性があ ると考えられた。血腫による明らかな脊髄圧迫所見 はなく, 発症後 24 時間以上経過していたこともあ 
り，外科的減圧術は行われなかった。その後患者は 3 力月後に死亡したが，その時点まで麻痺は残存し ていた。

次の症例報告は 84 歳の男性 ${ }^{6)}$. 69 歳で後縦勒帯 骨化症に対し頸椎拡大形成術を受けた既往がある. 前縦郭腫瘍摘出術が予定され, 硬膜外麻酔併用全身 麻酔が計画された。術前の血液凝固系検査はすべて 正常範囲内であった。第 $5 / 6$ 胸椎間にて硬膜外腔穿 刺を行うも 2 回失敗し, 施行者が交代して成功した. カテーテルは硬膜外腔に $5 \mathrm{~cm}$ 挿入した。術中・術 後に $0.2 \%$ ロピバカインを $4 \mathrm{~mL} / \mathrm{h}$ で投与した。術後 1 日目に立位可能になっていたが，夕方に両下肢の 異常知覚が出現, 術後 2 日目の朝に両下肢の運動麻 痺が出現した。そこで硬膜外注入を中止し, MRI 検査を行ったところ第 1 胸椎〜第 2 腰椎の血腫形成 と脊髄圧迫所見が見られた。麻痺発現から 10 時間 後に春椎椎弓切除術(第 1 第 8 胸椎), 血腫除去術 を行った。硬膜表面に静脈叢の発達所見があった。 椎弓切除術翌日に下肢の筋力は術前レベルまで回復 した。硬膜表面の静脈叢の発達は後縦勒带骨化症と 関連があるのかもしれない.

カテーテル抜去後に硬膜外血腫を生じた症例も報 告されている7). 患者は 63 歳の男性で胆囊摘出術, 左上葉肺癌手術, 軽度閉塞性換気障害, 糖尿病の既 往があった。右上葉肺癌に対し, 胸腔鏡下上葉切除, リンパ節郭清術が予定され, 硬膜外麻酔併用全身麻 酔が計画された。第 $6 / 7$ 胸椎間より傍正中法で硬膜 外腔を穿刺し, カテーテルを $5 \mathrm{~cm}$ 挿入した。術中 は $0.375 \%$ ロピバカインを適宜投与し，術後は $0.2 \%$ ロピバカインとフェンタニルの混合投与を $4 \mathrm{~mL} / \mathrm{h}$ で行った。手術当日の術後 1 時間後から未分画へパ リンの点滴静注が開始された。術後 1 日目の 10 時 30 分にヘパリンを終了し, 術後 2 日目の 9 時 6 分に 硬膜外カテーテルが抜去された。10時 9 分に両側ア キレス腱・膝蓋骨腱反射低下, 下肢筋力低下, 乳頭 線レベル以下の知覚消失が認められた。急性硬膜外 血腫を疑いヒドロコルチゾンを静注し，MRI検査
が施行された。第 4 ～6胸椎の硬膜外血腫が確認さ れた。この時点で凝固系検査に異常はなかった。そ の後，症状は急速に回復し，13時に運動麻痺と知 覚消失は完全に回復した。MRIの再検でも硬膜外 血腫の縮小と春髄圧迫の緩和が認められた。へパリ ン終了後 22 時間以上たってからカテーテルを抜去 し，血腫が生じた症例である。症状は急速に進み， また急速に自然回復した。

当施設でも硬膜外血腫が発生しているので紹介す る。血腫が生じた症例は 70 歳代の男性, 既往歴と して胸部大動脈溜に対する上行大動脈人工血管置換 術，腹部大動脈瘤に対する Y グラフト術の手術歴 と，脳梗塞があった。前立腺肥大に対し，某年 12 月 6 日に経尿道的ホルミウムレーザー前立腺核出術 を施行された。術後出血があり 11 日に止血術が行 われた。 24 日に再度出血にて止血術が施行された。 24 日の止血術は脊髄くも膜下麻酔, 硬膜外麻酔併 用で行い, 術後に $0.2 \%$ ロピバカイン，フェンタニ ルを用いた硬膜外持続鎮痛が行われた。25日の昼 頃，硬膜外カテーテルが自然抜去。同日 18 時頃よ り腰痛が出現した. 26 日 0 時頃より両下肢のしびれ， 知覚鈍麻，体動困難の訴えがあった。10時，麻酔 科に連絡がきて，緊急 MRIを施行．硬膜外血腫の 診断で緊急椎弓切除が行われた。手術後麻痺は少し ずつ改善したが，5年後の時点でも残存していた。

\section{2. 硬膜外膿瘍}

硬膜外膿瘍も自施設例を紹介する。

患者は50歳代の男性で糖尿病の既往はなく，身 体のどこかに感染の兆候があったということもなか つた ${ }^{8)}$. 主訴の右腰下肢痛に対し, MRI検査を行っ た結果第 11/12 胸椎領域の黄色勒帯肥厚, 第 5 腰椎/ 第 1 仙椎の椎間板ヘルニアの所見があった。持続硬 膜外ブロックによる治療を計画し，第 5 腰椎 / 第 1 仙椎間から硬膜外カテーテルを挿入した。患者自己 調節鎮痛法 $(1 \%$ メピバカイン $3 \mathrm{~mL} / \mathrm{h}$ ，ボーラス $3 \mathrm{~mL}$ ，ロックアウト 120 分)により疼痛コントロー ルは良好であったが，硬膜外カテーテル留置 12 日 
目に $37^{\circ} \mathrm{C}$ の発熱, 倦急感, 刺入部痛が発現した. 留置13日目に硬膜外カテーテルを抜去した。体温 は午後には $38.1^{\circ} \mathrm{C}$ に昇した。1 14 日目には項部硬 直，頭部前屈による上位胸椎レベルの疼痛(レール ミッテ徵候), 白血球増多, CRP上昇 $(6.6 \mathrm{mg} / \mathrm{dL})$ が 見られた。MRI 検査の結果，T2強調像で第 5 腰椎/ 第 1 仙椎レベル周囲の硬膜外腔の左背側部に $5 \times 20$ $\times 2 \mathrm{~mm}$ の扁平な炎症巣と思われる病変があった (図2)。セフォチアム投与により髄膜刺激症状と炎 症反応は改善した。カテーテル先端部の培養では表 皮ブドウ球菌が検出された。退院時のMRI検査で は病変は縮小し, 退院 1 力月後の検査では消失して いた（図3)。硬膜外膿瘍は易感染性を有する患者で 発生することが多いが，本症例のように全身状態が 良好な患者でも発生しうる。硬膜外膿瘍は予防が最 も重要であるが，良好な予後のためには早期発見と 治療開始が重要であるので感染を常に念頭に置いて 管理することが必要である。

\section{3. 脊髄梗塞}

春髄梗塞も硬膜外麻酔と関連して起こりうるが, 血腫よりさらにまれな合併症である。針による血管 の機械的損傷, 術中低血圧, 占拠性病変などが原因 となって生じるとされている。腫瘤性圧迫病変が虚 血や梗塞を引き起こす可能性もある．自施設での症 例はないので，国内の症例報告を紹介する。

患者は 75 歳の女性, 開腹による子宮付属器摘出 術を硬膜外麻酔併用全身麻酔にて施行された ${ }^{9}$ 。硬 膜外麻酔は第 $11 / 12$ 胸椎間からカテーテルを挿入 し，術中は $0.25 \%$ レボブピバカイン，フェンタニル 混合液の投与，術後は $0.2 \%$ レ゙ブピバカイン $4 \mathrm{~mL} / \mathrm{h}$ の持続注入を行った。術直後に下肢の知覚・運動は 回復していた。夜間より下肢の知覚・運動機能の低 下が見られ, 持続硬麻を注入中止後も症状は持続し, 第 5 胸髄レベル以下の知覚脱出, 下肢運動麻痺が見 られた。 MRI検査では硬膜外に腫瘤はなく, 黄色 勒帯の骨化と T2 強調像で第 8 胸髄レベルに hyperintense area(高信号域)が認められた。CT所見で
は硬膜外カテーテル先端が脊柱管の最狭窄部位に一 致して存在していた。その後カテーテルを抜去し， 保存的治療が行われたが，完全な回復には至ってい ない。これは脊柱管狭窄部位にカテーテルがいわば 腫瘤となって梗塞を引き起こしたと考えられた。こ の症例では低血圧は起こっていなかった。

\section{4. 硬膜穿刺後頭痛}

これまでの合併症と比べると頻度の多い合併症で ある。一般病院の帝王切開症例を対象とした後ろ向 き研究では，726件中治療を要する重症の硬膜穿刺 後頭痛が発生したのは 6 件で， $0.8 \%$ の発生率であっ た。この施設では硬膜外麻酔併用春髄くも膜下麻酔 が行われ，2 力所穿刺法で硬膜外麻酔は第 12 胸椎〜 第 2 腰椎からカテーテルを挿入し, 脊髄くも膜下麻 酔は第 3 ～腰椎間で $25 \mathrm{G}$ のペンシルポイント針を 使用して穿刺した。偶発的硬膜穿刺は 3 例あり，そ の全例で重症の硬膜穿刺後頭痛を発症した。明らか な偶発的硬膜穿刺がなかった症例も含めて 5 例でブ ラッドパッチが行われ，著効した。

大学病院ではどうだろうか？ 当院で 2016 年 1 月 1 日から 2019 年 7 月 31 日の間に硬膜外麻酔を施 行された全症例を対象に，麻酔記録に硬膜穿刺があ つたことが記載されていた症例を抽出した。その結 果，2,790例の硬膜外麻酔症例のうち，17例で硬膜 穿刺 (頻度 $0.61 \%)$ が起こっていた。これは麻酔記録 に硬膜穿刺が記載された症例数で，記載漏れなどの 見落としの可能性もあり，また頭痛の発生を調べた 前述の研究とは基準が異なるが，大学病院ではほと んどの硬膜外麻酔は後期研修医が施行していること を考慮すると，同程度であれば悪い結果ではないだ ろう。後期研修医の教育は難しいが，シミュレータ による訓練後に指導医の監視の下で手技を行い，困 難な症例では交代するなどの指導が適切に行われて いると考えている.

\section{5. 馬尾症候群}

脊髄神経は馬尾の部分で比較的長い距離春柱管を 走る。持続くも膜下麻酔など，脊髄くも膜下腔に投 

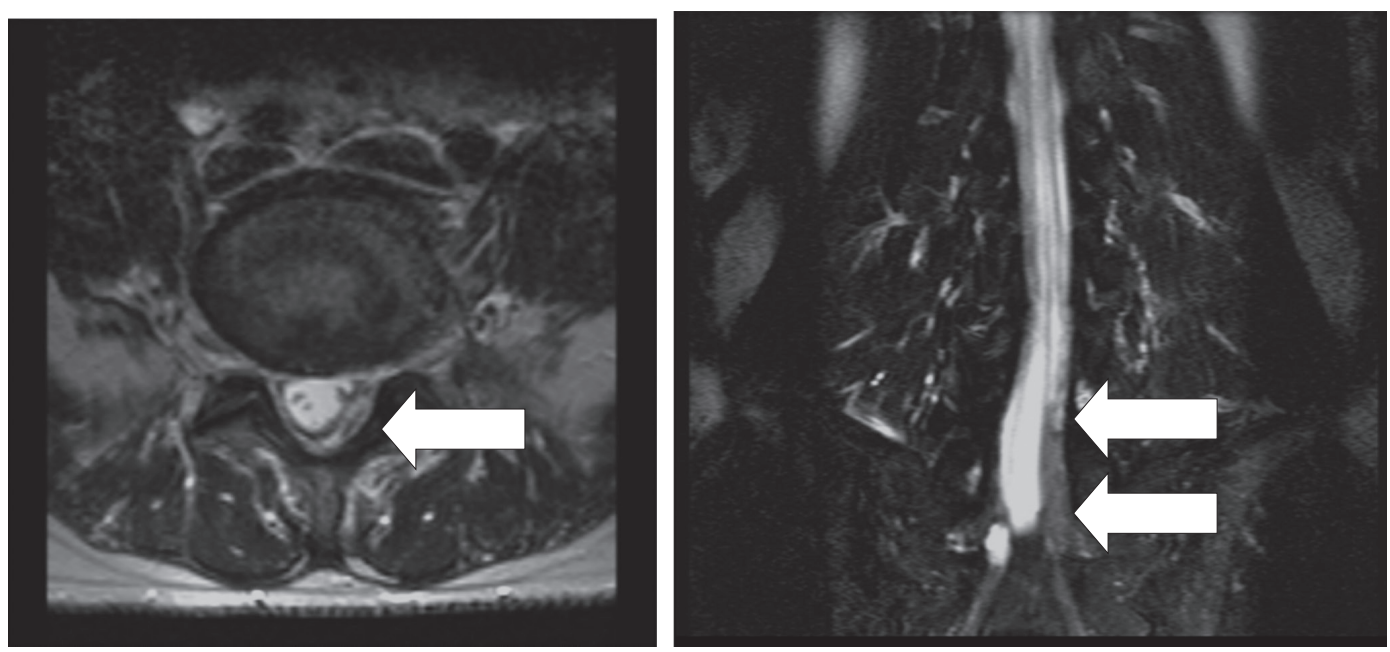

図2 硬膜外腔感染発症時の MRI, T2 強調像 (左 : 水平断面, 右 : 前頭断面) 矢印が病変部。
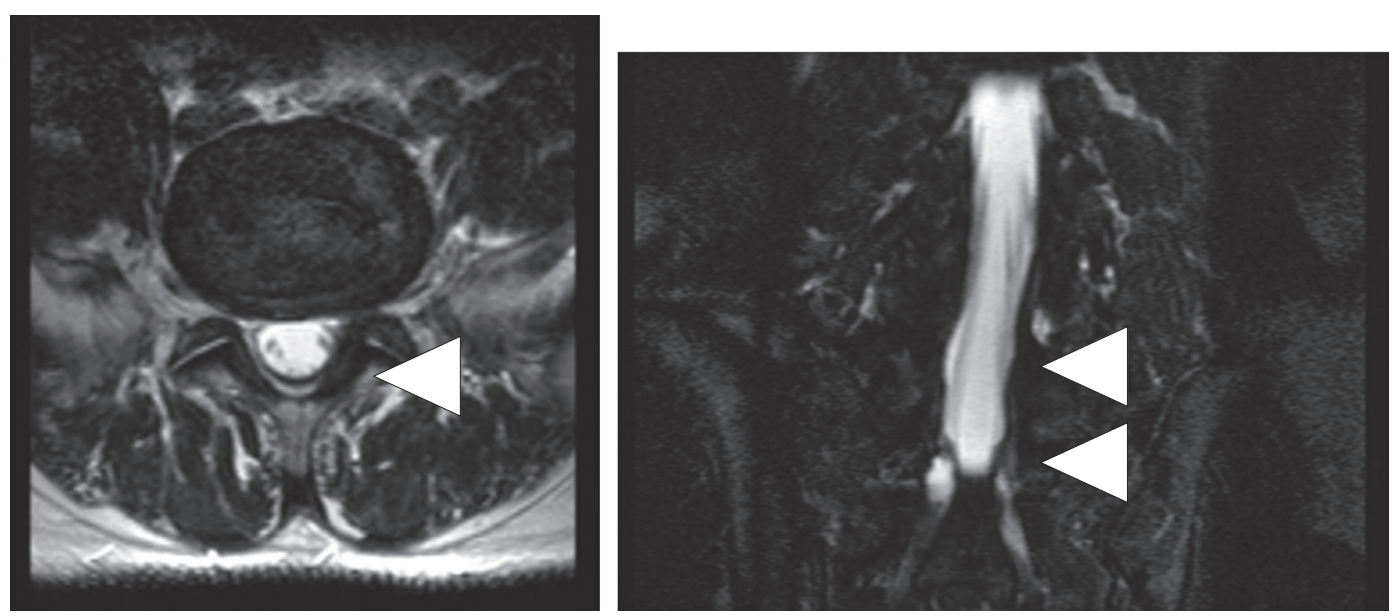

図3 退院 1 カ月後の MRI, T2 強調像 (左：水平断面, 右 : 前頭断面) 病変部はほぼ消失している。

与された局所麻酔薬の広がりが良くなかったとき， 局所で高濃度になり傷害を生じる可能性がある。馬 尾症候群は，馬尾の損傷により膀胱直腸障害と会陰 部の知覚障害，下肢の運動障害を生じる神経障害の 総称である。

筆者は 2 回の帝王切開術の麻酔の両方で術後に神 経障害の症状を呈した患者を経験している ${ }^{10)}$ 。患者 に既往歴はなかった。最初の帝王切開は 28 歳の時 で，麻酔はテトラカインを用いた脊䯣くも膜下麻酔
とメピバカインを用いた硬膜外麻酔の併用で行っ た。 31 歳で 2 回目の帝王切開の時は同様の麻酔のあ と, 術後はブピバカインとフェンタニルの混合液を 用いた硬膜外持続注入を行った。患者は 2 回とも術 後 7〜11日間の慰部痛と約半年間仙骨領域のしび れを生じた。この症例は患者側になんらかの症状を 起こしやすい要因があったのではないかと考えてい る. 


\section{6. その他}

その他にもさまざまな合併症があるが，比較的頻 度が高いものとして, 硬膜外カテーテルの位置異常 がある。硬膜外カテーテルのくも膜下腔への迷入も 発生しうる ${ }^{11}$ 。〈も膜下腔にカテーテルが挿入され ていても髄液の逆流が認められないこともあり，ま たいったん硬膜外腔に挿入されていたカテーテルが 時間経過とともにくも膜下腔に迷入してしまうこと も知られている ${ }^{12)}$. カテーテルがくも膜下に迷入し ていることに気づかずに局所麻酔薬を投与すると全 脊髄くも膜下麻酔になりうるので，投与するときは 少量ずつ分割投与するなど慎重に投与すべきであ る。静脈内迷入が多いが，開胸したら胸腔内にカテ ーテルがあったという症例もある ${ }^{13)}$.

\section{おわりに}

合併症は起こらないように予防することが重要で あるが，完全になくすことはできない.したがって 合併症が起こらないように丁寧な手技や慎重な薬物 投与を行った上で，合併症の早期発見と治療ができ るような体制作りが必要である。当院でもしばらく 前から周術期管理チームが術後の回診も行うように なった。残念ながら全症例ではなく，2019年の1月 〜 月で見ると全体の 3 分の 1 程度の 398 例である が，その中でも硬膜外麻酔の持続投与終了後もしび れがしばらく続く症例が 13 例と予想より多く見つ かった。症状が長期間続く症例はなかったが，フォ ローが不十分なまま終了してしまっている症例もあ ると思われる。

硬膜外麻酔に伴って軽度のものから重篤なものま でさまざまな合併症が発生する可能性がある。気づ かれていない合併症が多くある可能性もある。合併 症を早期に発見・対処するためには硬膜外麻酔の教 育とともに周術期管理体制の充実が重要である.

本論文の投稿に際し，所属施設における倫理委員
会の承認を得た。

本稿の要旨は日本臨床麻酔学会第 39 回大会 $(2019$ 年，軽井沢)で発表した。

\section{参考文献}

1) von Hösslin $T$, Imboden $P$, Lüthi $A$, et al. : Adverse events of postoperative thoracic epidural analgesia : a retrospective analysis of 7273 cases in a tertiary care teaching hospital. Eur J Anaesthesiol 33 : 708-714, 2016

2) Butler $\mathrm{AB}$, Green $\mathrm{CD}:$ Haematoma following epidural anaesthesia. Can Anaesth Soc J 17 : 635-639, 1970

3) Morisaki H, Doi J, Ochiai R, et al. : Epidural hematoma after epidural anesthesia in a patient with hepatic cirrhosis. Anesth Analg 80 : 1033-1035, 1995

4) Moen V, Dahlgren N, Irestedt L : Severe neurological complications after central neuraxial blockades in Sweden 1990-1999. Anesthesiology $101: 950-959,2004$

5）渡邊美由樹, 井上玲央, 池田貴充ほか：硬膜外麻酔が 関連すると思われた硬膜外血腫の 1 症例。麻醉 64 ： 1068-1071, 2015

6）大和田麻由子, 高橋宏, 山下創一郎ほか：脊椎疾患が 関係すると考えられた術後硬膜外血腫の 1 症例。麻酔 64:647-650, 2015

7）高橋均, 谷岡野人, 佐藤哲文：硬膜外カテーテル抜去 後の胸椎硬膜外血腫による春䯣麻㾇と自然回復の 1 症 例。麻酔 $62: 1207-1209,2013$

8）橋本龍也, 中谷俊彦, 橋本愛ほか：持続硬膜外ブロッ ク中に硬膜外䏶感染をきたした 1 例。日本ペインクリニ ック学会誌 $14: 414-417,2007$

9) Kobayashi K, Narimatsu N, Oyoshi T, et al. : Spinal cord infarction following epidural and general anesthesia : a case report. JA Clin Rep $3: 42,2017$

10) Sakura S, Toyota K, Doi K, et al. : Recurrent neurological symptoms in a patient following repeat combined spinal and epidural anaesthesia. Br J Anaesth 88 : 141-143, 2002

11）大内貴志, 印南靖志, 梅村直治ほか：ロピバカインの 偶発的なくも膜下投与により全脊髄くも膜下麻酔とな った 1 症例。麻醉 $56: 173-174,2007$

12) Drasner K, Rigler ML, Sessler DI, et al. : Cauda equina syndrome following intended epidural anesthesia. Anesthesiology $77: 582-585,1992$

13) Furuya A, Matsukawa T, Ozaki M, et al. : Interpleural misplacement of an epidural catheter. J Clin Anesth $10: 425-426,1998$ 


\title{
Cases of Complications after Epidural Anesthesia in Japan
}

\author{
Shinichi SAKURA ${ }^{* 1}$, Kaoru HARA ${ }^{* 2}$ \\ ${ }^{* 1}$ Surgical Center, University Hospital, Faculty of Medicine, Shimane University \\ ${ }^{* 2}$ Department of Anesthesiology, Matsue Seikyo General Hospital
}

\begin{abstract}
Epidural anesthesia is widely used for intraoperative and postoperative analgesia, but it can lead to various complications. Although most of these are minor, such as nausea, vomiting, hypotension and urinary retention, serious complications can occur as well, resulting in permanent nerve injury. Spinal epidural hematoma and epidural abscess are among the most serious and well-known complications. This paper describes cases of complications after epidural anesthesia which have occurred in our hospital and been reported in the literature from Japan. We should provide proper education for young clinical fellows to reduce the incidence of complications resulting from improper procedures. An acute pain service can play an important role in early detection and early treatment of these complications.
\end{abstract}

Key Words : Epidural anesthesia, Complications, Spinal epidural hematoma, Epidural abscess

The Journal of Japan Society for Clinical Anesthesia Vol.40 No.3, 2020 